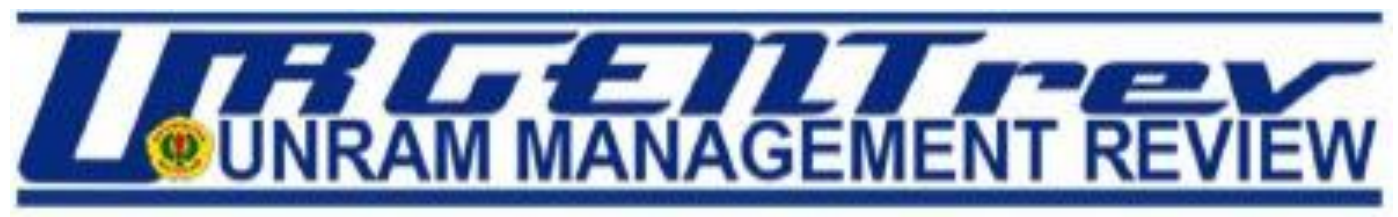

Vol. 1 No. 1 Oktober 2021

e.ISSN. $2809-4263$

urgentrev.unram.ac.id

\title{
PENGARUH PROMOSI DI MEDIA SOSIAL DAN GAYA HIDUP TERHADAP MINAT BELI DI TOKO ONLINE
}

\author{
Mauizatul Hasanati, Lalu Adi Permadi, Weni Retnowati \\ Fakultas Ekonomi dan Bisnis \\ Universitas Mataram \\ E-mail: mauizohasanati99@gmail.com \\ DOI: https://doi.org/10.29303/ju.v1i1.26
}

\begin{abstract}
ABSTRAK
Penelitian ini bertujuan untuk menguji variabel promosi di media sosial dan gaya hidup terhadap Minat Beli di Toko online. Jenis penelitian yang digunakan adalah penelitian asosiatif. Populasi dalam penelitian ini adalah semua Masyarakat yang mengetahui Toko online di NTB. Jumlah sampel dalam penelitian ini adalah 100 responden. Teknik pengambilan sampel menggunakan metode nonprobability sampling. Analisis yang digunakan adalah analisis uji regresi linier berganda. Hasil dari penelitian ini menunjukkan bahwa variabel promosi di media sosial tidak berpengaruh signifikan terhadap minat beli konsumen dengan sedangkan variabel gaya hidup berpengaruh signifikan dan positif terhadap minat beli di Toko online
\end{abstract}

\section{Kata Kunci : Promosi di Media Sosial, Gaya hidup, Minat Beli}

\section{ABSTRACT}

This study aimed to examine the variable promotion on social media and lifestyle towards buying interest in online stores. The method of the research used was associative research. The population in this study were all people who saw all respondents' online shops in NTB, the number of samples in this study were 100 respondents. The sampling technique used was nonprobability sampling method. The analysis used multiple linear regression analysis. The results of this study indicated that the promotion variable on social media had no significant effect on consumer purchase interest. Lifestyle variables that had a significant and positive effect on buying interest in online store.

Keywords: Promotion on Social Media, Lifestyle, Purchase Interest 


\section{PENDAHULUAN}

Teknologi komunikasi, media, dan informasi yang semakin berkembang pesat, serta meluasnya perkembangan infrastruktur informasi global telah membawa pengaruh pola kegiatan bisnis industri perdagangan, pemerintah sosial, politik, dan ekonomi. Hal itu didukung dengan pernyataan Rahardjo (2002) yaitu adanya teknologi informasi dapat membantu mengatasi masalah, kendala atau ketidakmampuan kita pada sesuatu. Internet sudah menjadi suatu hal yang biasa bahkan sudah menjadi kebutuhan bagi beberapa orang atau perusahaan. Kontribusi internet sebagai media komunikasi pemasaran dan transaksi perdagangan telah memunculkan toko online sebagai media baru dalam berbelanja dan memudahkan konsumen untuk membeli barang yang ia inginkan tanpa harus pergi ke toko.

Menurut Putri (2020), dengan adanya trend ini, perusahaan diharuskan mengikuti perkembangan teknologi informasi dengan salah satu cara yaitu mengenalkan dan memasarkan produk secara online atau e-marketing untuk mencapai seluas-luasnya ke pasar potensial yang dijadikan sasaran. Menurut Kotler \& Armstrong (2008) e-marketing adalah sisi pemasaran dari e-commerce, yang terdiri dari kerja perusahaan untuk mengkomunikasikan sesuatu, mempromosikan dan menjual produk dan jasa melalui internet. Salah satu jenis $e$ commerce atau situs jual beli online yang saat ini berkembang pesat di Indonesia adalah e-commerce jenis marketplace. Marketplace merupakan sebuah tempat secara online dimana penjual dapat membuat akun dan menjajakan barang dagangannya. Salah satu keuntungan berjualan di marketplace adalah penjual hanya perlu menyediakan foto produk dan mengunggahnya yang kemudian dilengkapi dengan deskripsi produk tersebut.

Pertumbuhan marketplace di Indonesia didominasi oleh penjual ritel seperti fashion, kesehatan dan berbagai macam produk. Pertumbuhan yang sangat pesat ini didukung oleh kehadiran market place seperti Shopee, Tokopedia, Lazada, Bukalapak dan banyak toko online lainnya. Dengan adanya toko online ini pelaku bisnis harus mampu memanfaatkan secara optimal untuk dapat menarik minat beli konsumen. Sehingga pemasaran tradisional mulai ditinggalkan oleh para pemasar dan berganti secara online salah satunya menggunakan media sosial sebagai sarana promosi.

Menurut Kotler \& Keller (2016) media sosial adalah media yang digunakan oleh konsumen untuk berbagi teks, gambar, suara, dan video informasi baik dengan orang lain maupun perusahaan dan sebaliknya. Promosi media sosial dilakukan dengan memasarkan produknya melalui akun media sosial pribadi yang dimilikinya seperti Facebook, instagram, Youtube, Whatsapp, dan Wechat atau membuat akun media sosial khusus untuk produk yang ditawarkannya. Dengan promosi di media sosial akan meningkatkan minat beli konsumen karena para pemasar akan dengan mudahnya dapat membangun suatu hubungan dengan konsumen sehingga perusahaan akan mudah memberikan update tentang produk, membujuk konsumen, dan memungkinkan untuk mendapatkan feedback dari konsumen. Berdasarkan penelitian yang dilakukan oleh Hudha (2018) mengemukakan bahwa promosi melalui media sosial berpengaruh signifikan terhadap minat beli sehingga dapat dikatakan semakin tinggi tingkat promosi melalui media sosial maka akan semakin tinggi juga minat beli konsumen. Jika perusahaan memiliki media sosial maka konsumen akan mudah untuk menemukan produk dan informasi yang dicarinya. Promosi melalui internet khususnya dengan sosial media dapat meningkatkan penjualan secara luas dan tidak memerlukan biaya pemasaran yang mahal.

Seiring perkembangan zaman promosi di media sosial juga sudah menjadi 


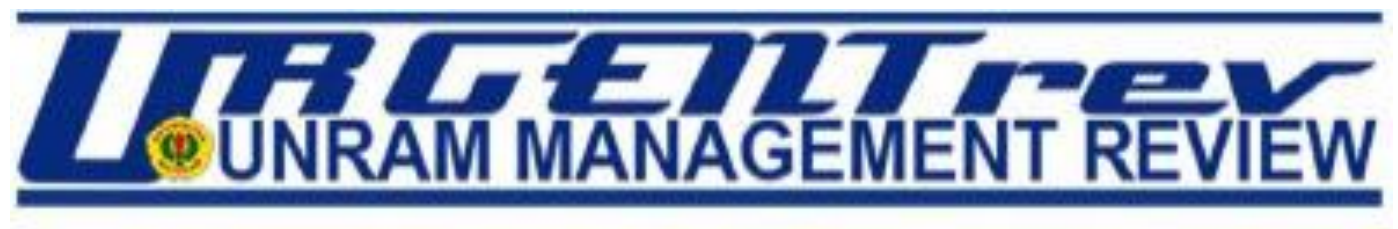

gaya hidup masyarakat saat ini di lihat dari aktivitas serba online. Menurut Sathish \& Rajamohan (2012) gaya hidup adalah sebuah sistem yang terintegrasi dari sikap, nilai-nilai, kepentingan, pendapat, dan tingkah laku seseorang. Menurut Sumarwan dalam Listyorini (2012) menjelaskan bahwa gaya hidup seringkali digambarkan dengan kegiatan, minat dan opini dari seseorang, dan menggambarkan perilaku seseorang, yaitu bagaimana mereka hidup, menggunakan uangnya dan memanfaatkan waktu yang dimilikinya . Dari berbagai pendapat diatas dapat disimpulkan bahwa gaya hidup adalah pola seseorang yang dinyatakan dalam kegiatan, minat dan pendapatnya dalam membelanjakan uangnya dan bagaimana mengalokasikan waktu. Hal ini didukung dengan penelitian yang dilakukan oleh Rubiati \& Heriyana (2020) yang menyatakan hasil bahwa gaya hidup berpengaruh signifikan terhadap minat beli konsumen secara online. Sehingga dapat dikatakan bahwa semakin modern atau maju gaya hidup seseorang maka semakin tinggi pula minat beli di Toko online.

Menurut Kumala (2012) minat beli berhubungan dengan rencana konsumen untuk membeli, serta berapa banyak unit produk atau jasa yang dibutuhkan pada periode tertentu. Faktor-faktor yang mempengaruhi minat beli yang biasa yang ada di benak konsumen yaitu seperti kualitas, brand/merek dan harga apabila faktor-faktor tersebut memenuhi keinginnan konsumen maka akan timbulnya minat beli konsumen. Minat beli juga merupakan kemungkinan konsumen akan membeli sebuah produk atau jasa. Sebuah peningkatan dalam minat beli berarti peningkatan pada kemungkinan dilakukan pembelian. Minat beli diartikan sebagai sebuah keinginan konsumen untuk membeli sebuah produk dan jasa. . Ketika seseorang telah memiliki kepuasan atas produk yang telah dibeli, maka hal ini akan memunculkan preferensi atas pengalaman pembelian jika konsumen akan membeli produk yang sama di masa yang akan datang. Keputusan untuk mengadopsi atau menolak suatu produk timbul setelah konsumen mencoba suatu produk tersebut dan kemudian timbul rasa suka atau tidak suka terhadap produk tersebut.

Berdasarkan pemaparan tersebut peneliti tertarik melakukan penelitian terkait dengan teori-teori yang di bahas, yakni terkait dengan promosi di media sosial dan gaya hidup yang nantinya penelitian ini di lakukan di Provinsi Nusa Tenggara Barat . Peneliti ini tertarik membuat penelitian yang berjudul pengaruh Promosi Di Media Sosial Dan Gaya Hidup Terhadap Minat Beli Di Toko Online dengan rumusan masalah sebagai berikut :

1. Apakah promosi di media sosial mempunyai pengaruh signifikan terhadap minat beli di Toko online?

2. Apakah gaya hidup mempunyai pengaruh signifikan terhadap minat beli di Toko online?

\section{KAJIAN PUSTAKA \\ Minat Beli}

Menurut Sukmawati \& Durianto (2003) mengungkapkan bahwa minat beli adalah keinginan untuk memiliki produk, minat beli akan timbul apabila seseorang konsumen sudah terpengaruh terhadap suatu kualitas dan informasi seputar produk contoh: harga, cara membeli dan kelemahan serta keunggulan produk dibanding merek lain. Dari teori tersebut, dapat disimpulkan bahwa minat beli merupakan dorongan pada seseorang atau perusahaan untuk melakukan pembelian pada suatu produk atau jasa sesuai dengan kebutuhan dan keinginannya.

Menurut Ferdinand (2002) minat beli dapat diidentifikasi melalui beberapa indikator sebagai berikut:

a. Minat referensial yaitu kecenderungan seseorang untuk mereferensikan suatu produk kepada orang lain.

b. Minat preferensial yaitu minat yang menggambarkan perilaku seseorang yang memiliki preferensi utama pada suatu produk. Preferensi dapat diganti 
jika terjadi sesuatu dengan produk tersebut.

c. Minat eksploratif minat ini menggambarkan perilaku seseorang yang selalu mencari informasi mengenai suatu produk yang diminatinya dan mencari informasi untuk mendukung sifat-sifat positif dari produk tersebut.

\section{Promosi di Media Sosial}

Promosi sebagai unsur utama dalam kampanye pemasaran merupakan kumpulan alat-alat yang insentif yang sebagian besar berjangka pendek, yang dirancang untuk merangsang pembelian produk atau jasa tertentu dengan lebih cepat dan lebih besar oleh konsumen atau pedagang Kotler \& Keller (2009). Selanjutnya Tjiptono (2008) menyatakan bahwa promosi merupakan salah satu faktor penentu keberhasilan suatu program pemasaran untuk memberikan informasi mengenai adanya suatu produk.

Dari definisi diatas dapat dikatakan bahwa promosi merupakan cara perusahaan memperkenalkan produknya dan mempengaruhi minat beli konsumen. Media sosial menurut Kotler \& Keller (2012), merupakan sarana bagi konsumen yang digunakan untuk berbagai teks, gambar, audio, dan informasi video dengan sesama pengguna maupun sebuah perusahaan. Media sosial juga mengubah cara konsumen berkomunikasi dan berbagi informasi sehingga kini konsumen mampu berdiskusi, beropini, dan membagi pengalaman Nielsen (2011). Menurut Saragih \& Ramdhany (2012) media sosial adalah media online yang mendukung interaksi sosial dan media sosial menggunakan teknologi berbasis web yang mengubah komunikasi menjadi dialog interaktif. Dari definisi diatas dapat disimpulkan bahwa media sosial merupakan media promosi yang lebih tepat dan dapat terjadi komunikasi interaktif yang melibatkan antara penjual dengan produk-produknya.
Menurut Ekasari (2014) indikator promosi media sosial yaitu:

1. Relationship media sosial yaitu membangun hubungan dengan konsumen melalui media yang ada.

2. Komunikasi dalam media sosial yaitu interaksi yang terjadi antara penjual dengan konsumen.

3. Interaksi pasca pembelian dalam media sosial yaitu interaksi yang terjadi dengan konsumen setelah konsumen membeli produk

4. Informasi dalam media sosial yaitu menyampaikan suatu informasi dengan lengkap dan dapat menarik perhatian konsumen.

\section{Gaya Hidup}

Gaya hidup adalah pola hidup seseorang di dunia yang tercermin dalam kegiatan, minat, dan pendapat. Gaya hidup memotret interaksi seseorang secara utuh dengan lingkungannya (Kotler \& Keller (2009), menurut Mowen dan Minor dalam Sangadji (2013) gaya hidup menunjukan bagaimana seseorang menjalankan hidup, membelanjakan uang, dan memanfaatkan waktunya.

Menurut Kotler \& Keller (2012) gaya hidup seseorang adalah pola hidup seseorang dalam dunia kehidupan seharihari yang dinyatakan dalam kegiatan, minat dan pendapat yang bersangkutan. MenurutKotler \& Armstrong (2008) gaya hidup merupakan pola hidup seseorang yang dapat menggekpresikan dalam keadaan psikografisnya.

Menurut Women dalam Pangestu dan Suryoko (2016) merupakan gaya hidup mempengaruhi perilaku seseorang yang pada akhirnya menentukan pola konsumsi seseorang. Adapun indikator gaya hidup antara lain:
a. Utilitarian purchase yaitu pembelian produk yang bermanfaat.
b. Indugence dalam gaya hidup yaitu kemewahan
c. Life luxuries yaitu kemewahan dalam hidup




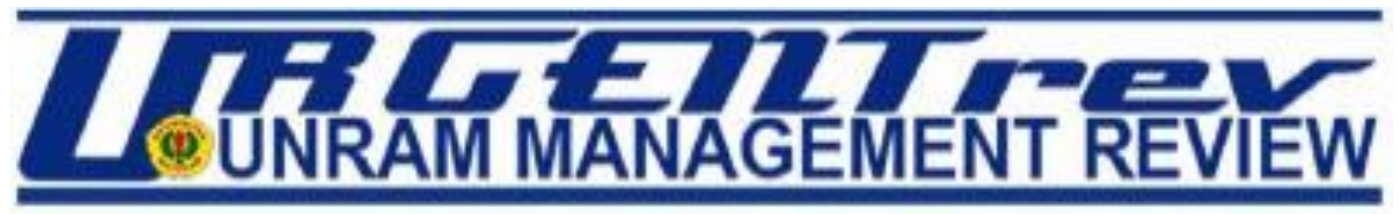

Vol. 1 No. 1 Oktober 2021

d. Aspirational luxuries yaitu kemewahan aspiratip

\section{METODE PENELITIAN}

Penelitian ini merupakan penelitian asosiatif dengan pendekatan kuantitatif, berlokasi di provinsi Nusa Tenggara Barat. Metode pengumpulan data yang digunakan dalam penelitian ini adalah sampel survey. Penentuan pengambilan jumlah sampel dilakukan melalui teknik non probability sampling dengan metode purposive sampling, teknik pengumpulan data menggunakan angket dan online survey. Alat pengumpulan data berupa kuisioner yang disebar secara online. Skala pengukuran variabel menggunakan skala interval dari jenjang 1-5.

Tabel 1. Skala Interval

\begin{tabular}{|c|c|c|}
\hline No & $\begin{array}{c}\text { Kriteria Jawaban } \\
\text { Responden }\end{array}$ & Skor \\
\hline 1 & Sangat Setuju & 5 \\
\hline 2 & Setuju & 4 \\
\hline 3 & Netral & 3 \\
\hline 4 & Tidak Setuju & 2 \\
\hline 5 & Sangat Tidak Setuju & 1 \\
\hline
\end{tabular}

\section{HASIL DAN PEMBAHASAN}

Berdasarkan hasil uji validitas, menunjukan bahwa nilai dari setiap item pernyataan dalam kuesioner sudah valid dengan signifikansi kurang dari 0,05 serta nilai $\mathrm{r}$ hitung lebih besar dari $\mathrm{r}$ tabel $(\mathrm{r}$ hitung > $\mathrm{r}$ tabel), sehingga pernyataan dianggap valid dan dapat digunakan untuk analisis lebih lanjut. Hal ini berarti bahwa setiap item pernyataan dari kuesioner yang disebar kepada responden dapat dimengerti atau diterima.

Uji reliabilitas juga menunjukkan bahwa nilai dari Cronbach's Alpha dari setiap variabel lebih besar dari 0,7 sehingga dapat disimpulkan bahwa kuesioner dalam penelitian ini reliabel.

Berdasarkan hasil data analisis regresi linier yang telah di olah dalam penelitian ini didapatkan hasil persamaan regresi sebagai berikut : urgentrev.unram.ac.id

Tabel 2. Hasil Uji Regresi Linier Berganda

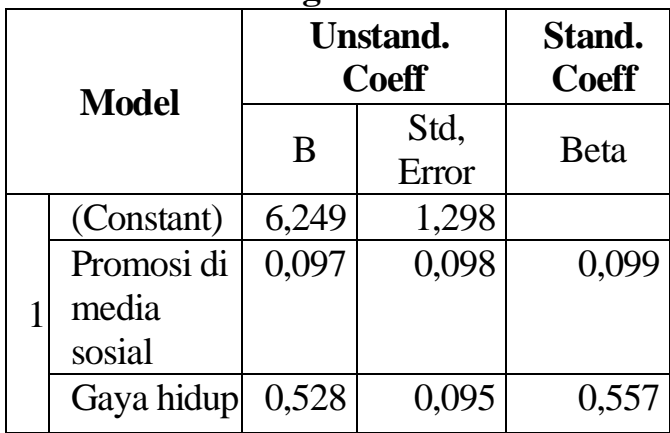

Sumber :Data Primer Diolah 2021

Dari Tabel 2 di atas dapat diperoleh suatu persamaan regresi sebagai berikut:

$$
\mathrm{Y}=6,249+0,097 \mathrm{X} 1+0,528 \mathrm{X} 2+\mathrm{e}
$$

Selanjutnya berdasarkan uji kelayakan model (uji f) yang telah di olah dalam penelitian ini, di dapatkan hasil sebagai berikut :

Tabel 3. Hasil Uji Simultan (Uji F)

\begin{tabular}{|c|c|c|c|c|c|}
\hline & Model & Df & $\begin{array}{c}\mathbf{F} \\
\text { Tabel }\end{array}$ & $\begin{array}{c}\text { F } \\
\text { Hitung }\end{array}$ & Sig. \\
\hline & $\begin{array}{l}\text { Regressio } \\
\mathrm{n}\end{array}$ & 2 & \multirow{3}{*}{3,09} & \multirow{3}{*}{30,652} & \multirow{3}{*}{$\underset{\mathrm{b}}{0,000}$} \\
\hline & Residual & 93 & & & \\
\hline & Total & 95 & & & \\
\hline
\end{tabular}

Sumber : Data Primer Diolah 2021

Berdasarkan Tabel 3 di peroleh $\mathrm{F}$ hitung sebesar 30,652 dan signifikan 0,000. Nilai $\mathrm{F}$ hitung lebih besar dibandingkan $\mathrm{F}$ Tabel $(30,652>3,09)$ yang artinya Ho ditolak Ha diterima dan nilai signifikan lebih kecil dari $0,05(0,00<0,05)$, sehingga dinyatakan bahwa model sudah layak.

Berikutnya berdasarkan dari hasil uji parsial (uji t) yang telah diolah dalam penelitian ini, didapatkan hasil sebagai berikut : 


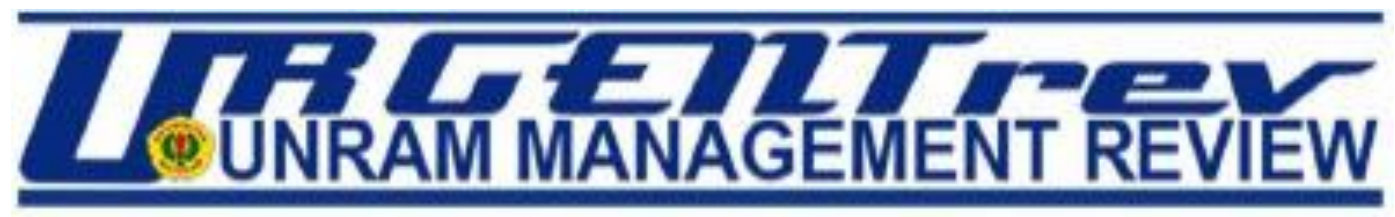

Vol. 1 No. 1 Oktober 2021

e.ISSN. $2809-4263$

urgentrev.unram.ac.id

Tabel 4. Hasil Uji Parsial (Uji T)

\begin{tabular}{|c|l|c|c|c|}
\hline $\begin{array}{c}\mathbf{N} \\
\mathbf{o}\end{array}$ & Data & $\begin{array}{c}\text { Asym } \\
\mathbf{p . S i g} \\
\mathbf{( 2 -} \\
\text { tailed) }\end{array}$ & $\begin{array}{c}\mathbf{T} \\
\text { hitun } \\
\mathbf{g}\end{array}$ & Hasil \\
\hline 1 & $\begin{array}{l}\text { Promos } \\
\text { i di } \\
\text { media } \\
\text { sosial }\end{array}$ & 0,327 & $\begin{array}{c}0,98 \\
5\end{array}$ & $\begin{array}{c}\text { Ho } \\
\text { diterima }\end{array}$ \\
\hline 2 & $\begin{array}{l}\text { Gaya } \\
\text { hidup }\end{array}$ & 0,000 & 5,5 & $\begin{array}{c}\text { Ho } \\
\text { ditolak }\end{array}$ \\
\hline
\end{tabular}

Sumber : Data Primer Diolah 2021

Berdasarkan hasil penguji pada Tabel 4. maka pengaruh promosi di media sosial dan gaya hidup terhadap minat beli dapat dijelaskan sebagai berikut:

1. Pengujian Hipotesis Pertama

Berdasarkan Tabel 4 diperoleh hasil bahwa variabel $\mathrm{X}_{1}$ memiliki nilai $\mathrm{t}$ hitung sebesar 0,985 signifikan sebesar 0,327. Nilai $\mathrm{t}$ hitung lebih kecil dibandingkan $\mathrm{t}$ Tabel $(0,985$ < 1,98 ) dan nilai signifikan lebih besar dari $0,05(0,327>0,05)$ menunjukkan bahwa promosi di media sosial tidak mempengaruhi minat beli secara statistic.

2. Penguji Hipotesis Kedua

Berdasarkan Tabel 4 diperoleh hasil bahwa variabel $\mathrm{X}_{2}$ memiliki t hitung 5,546 dengan signifikan 0,000 . Nilai $t$ hitung lebih besar di banding t Tabel $(5,546>1,98)$ dan nilai signifikan lebih kecil dari $0,05(0,000<0,05)$ menunjukkan bahwa gaya hidup mempengaruhi minat beli secara statistik.

Selanjutnya dari data koefisien determinan $\left(\mathrm{R}^{2}\right)$ yang telah diolah, didapatkan hasil sebagai berikut :

Tabel 5. Uji Koefisien Determinasi

\begin{tabular}{|c|c|c|r|}
\hline \multicolumn{4}{|c|}{ Model Summary $^{\mathbf{b}}$} \\
\hline Model & $\mathbf{R}$ & $\begin{array}{c}\mathbf{R} \\
\text { Square }\end{array}$ & $\begin{array}{c}\text { Adj. } \\
\mathbf{R} \\
\text { Square }\end{array}$ \\
\hline 1 & $0,622^{\mathrm{a}}$ & 0,387 & 0,375 \\
\hline
\end{tabular}

Berdasarkan hasil perhitungan koefisien regresi dalam penelitian ini diperoleh nilai Adjusted $R$ Square sebesar 0,387 . Hal ini berarti variabel independen dapat menjelaskan variasi dari variabel dependen sebesar $37,5 \%$ sedangkan sisa 62,5 dijelaskan oleh factor-faktor lain yang diteliti.

\section{KESIMPULAN}

Hasil analisis secara simultan diketahui bahwa variabel promosi di media sosial dan gaya hidup secara bersamaan berpengaruh tehadap minat beli di Toko online. Kondisi ini dapat ditunjukan dengan tingkat signifikan yang dihasilkan dari variabel promosi di media sosial dan gaya hidup. Hasil pengujian secara parsial untuk variabel promosi di media sosial menunjukan bahwa promosi dimedia sosial di toko online tidak berpengaruh signifikan dan positif terhadap minat beli konsumen dalam mempromosikan produk di Toko online di Provinsi Nusa Tenggara Barat. Hal ini menunjukkan bahwa promosi di media sosial tidak berpengaruh terhadap minat beli di Toko online secara statistik.

Berdasarkan hasil pengujian secara persial pada variabel gaya hidup menunjukan bahwa variabel gaya hidup pengaruh yang signifikan dan positif terhadap minat beli produk di Toko online di Provinsi Nusa Tenggara Barat. Secara empirik hal ini dapat dibuktikan dengan uji hipotesis secara pasial dimana menunjukkan bahwa gaya hidup berpengaruh terhadap minat beli di Toko online secara statistik.

Besaran Pengaruh Variabel promosi di media sosial dan gaya hidup terhadap minat beli di Toko online yang diperoleh dari hasil uji koefisien yakni sebesar 37,5 $\%$, hal ini menunjukan korelasi atau hubungan antara variabel yang dijadikan model dalam penelitian ini secara simultan terhadap minat beli di Toko online memiliki hubungan yang cukup erat.

\section{Daftar Pustaka}

Ekasari, N. (2014). Pengaruh promosi 
berbasis sosial media terhadap keputusan pembelian produk jasa pembiayaan kendaraan pada PT. BFI Finance Jambi. Jurnal Penelitian Universitas Jambi: Seri Humaniora, 16(2), 43450. Journal of Chemical Information and Modeling, 16, 81102.

Ferdinand, A. (2002). Pengembangan Minat Beli Merek Ekstensi.Badan Penerbit Universitas Diponegoro. Semarang.

Hudha, A. N. (2018). Promosi Melalui Media Sosial Terhadap Minat Beli. Universitas Sebelas Maret.

Kotler, P., \& Armstrong, G. (2008). Prinsip-Prinsip Pemasaran. In Manajemen Pemasaran (12 Edition).

Kotler, P., \& Keller, K. (2009). Manajemen Pemasaran (13th ed.). Erlangga.

Kotler, P., \& Keller, K. (2012). Marketing Management (14th ed.). Erlangga

Kotler, P., \& Keller, K. (2016). Marketing Management. In Person Education (15th).

Kumala, O. B. (2012). Pengaruh Word of Mouth Terhadap Minat Beli Konsumen Pada Tune Hotels Kuta Bali. (Vol. 3, Issue 12). Universitas Indonesia.

Listyorini, S. (2012). Analisis FaktorFaktor Gaya Hidup Dan Pengaruhnya Terhadap Pembelian Rumah Sehat Sederhana (Studi pada Pelanggan Perumahan Puri Dinar Mas PT. Ajisaka di Semarang). Jurnal Administrasi Bisnis Undip, 1(1), 1224.

Nielsen. (2011). The digital media habits and attitudes of seoutheast asian consumers.

http://www.nielsen.com/us/en/reports /2011/south-east-\%0Aasian-digitalconsumer-habits.html\%0A

Putri, D. A. (2020). Pengaruh Social Media Marketing Terhadap Keputusan Pembelian Pada Singapore Airlines. Universitas Mataram.

Rahardjo, B. (2002). Memahami Teknologi Informasi. In Elex Media
Komputindo. $\quad$ Elex $\quad$ Media Komputindo.

Rubiati, \& Heriyana. (2020). Pengaruh Gaya Hidup dan Kemudahan Terhadap Minat Beli Mahasiswa dalam Berbelanja Online. Jurnal Aplikasi Manajemen Dan Bisnis, 1(1), 57-65.

Sangadji, E. M. (2013). Prilaku KonsumenPendekatan Praktis Disertai Himpunan Jurnal Penelitian. Yogyakarta: Andi.

Saragih, H., \& Ramdhany, R. (2012). Pengaruh Intensi Pelanggan Dalam Berbelanja Online Kembali Melalui Media Teknologi Informasi Forum Jual Beli (Fjb) Kaskus. Jurnal Sistem Informasi, 8(2), 100.

Sathish, S., \& Rajamohan, A. (2012). Consumer behaviour and lifestyle Vietnam. International Journal of Marketing, Financial Services \&Management Research, 1(10), 153-166.

Sukmawati, P., \& Durianto. (2003). Manajemen Pemasaran. Erlangga.

Tjiptono, F. (2008). Manajemen pemasaran. Yogyakarta: Andi. 